\title{
Vertebrates visiting natural waterholes in a tropical seasonal
} habitat in central México

\section{Vertebrados que visitan pozos de agua naturales en un hábitat estacional tropical en el centro de México}

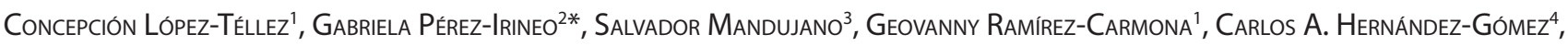 \\ and Diana E. Flores-Ramírez \\ 1'Facultad de Ciencias Biológicas, Benemérita Universidad Autónoma de Puebla. Sur 104, Col. Centro, C. P. 72000 . Puebla, México. \\ E-mail: amadea01@hotmail.com (CL-T); spiral.vann@gmail.com (GR-C). \\ ${ }^{2}$ Investigadora Independiente. C. P. 52777. Huixquilucan, Estado de México, México. E-mail: gabyirineo@yahoo.com.mx (GP-I). \\ ${ }^{3}$ Red de Biología y Conservación de Vertebrados, Instituto de Ecología A. C. Camino Antiguo a Coatepec, El Haya, C. P. 91070. \\ Xalapa, Veracruz, México. E-mail: salvador.mandujano@inecol.mx (SM). \\ ${ }^{4}$ Programa de Posgrado, Instituto de Ecología A. C. Camino Antiguo a Coatepec, El Haya, C. P. 91070. Xalapa, Veracruz, México. \\ E-mail: carloshernandez1196@gmail.com (CAH-C); diana.flores@posgrado.ecologia.edu.mx (DEF-R). \\ *Corresponding author
}

The spatial and temporal distribution of water availability impacts the behavior of species. Particularly in arid habitats, waterholes are sources of water for many species. Herein, records of vertebrates are describing visiting natural waterholes by camera traps during the dry season in a dry tropical forest of central México. During the dry season (December 2015, May 2016, and April-May 2019), we placed seven camera traps during 135 days in seven waterholes. This method was used as part of monitoring and conservation activities, implemented within an extensive wildlife management unit in central Mexico. We recorded a total of 20 vertebrates visiting the waterholes: 15 mammals, four birds, and one reptile. The coexistence between species without negative interactions, and some recorded conduct included: playful behavior, grooming and rubbing against stones; we observed some species waiting for their turn to drink. At least four individuals of Mephitis macroura were identified. Our study also emphasizes a basic aspect, but perhaps underestimated in recent years resulting from the use of camera traps: the qualitative observation of animals through photos. These observations can reveal basic and interesting aspects of the natural history of species that allow us to improve the knowledge about coexistence in the same place.

Key words: Camera traps; Mephitis macroura; non-lethal interactions; Urocyon cinereoargenteus.

La distribución espacial y temporal de la disponibilidad de agua impacta el comportamiento de las especies. Particularmente en hábitats áridos, los pozos de agua son fuentes de agua para muchas especies. Presentamos registros interesantes de vertebrados que visitaron pozos de agua naturales mediante cámaras-trampa durante la estación seca en un bosque tropical seco del centro de México. Durante la estación seca (diciembre de 2015, mayo de 2016 y abril-mayo de 2019), colocamos siete cámaras-trampa durante 135 días en siete pozos de agua. Este método utilizado fue parte de las actividades de monitoreo y conservación, implementadas dentro de una amplia unidad de manejo de vida silvestre en el centro de México. Registramos 20 especies de vertebrados visitando los pozos de agua: 15 mamíferos, cuatro aves, y un reptil. La co-ocurrencia entre especies sin interacciones negativas, y algunos registros de conducta incluyeron: eventos de juego, acicalamiento y frotamiento contra piedras; se observó a algunas especies esperando su turno para beber. Pudimos identificar al menos cuatro individuos de Mephitis macroura. Nuestro estudio también enfatiza un aspecto básico, pero quizás subestimado en los últimos años producto del uso de cámaras-trampa: la observación cualitativa de animales a través de fotografías. Estas observaciones pueden revelar aspectos básicos e interesantes de la historia natural de las especies que permiten mejorar el conocimiento sobre la coexistencia en un mismo lugar.

Palabras clave: Cámaras trampas; interacciones no letales; Mephitis macroura; Urocyon cinereoargenteus.

(C) 2021 Asociación Mexicana de Mastozoología, www.mastozoologiamexicana.org

The spatial and temporal distribution of water availability impacts foraging behavior, activity times, and microhabitat use of species (Rosenstock et al. 1999; Tanner et al. 2015). Particularly in arid habitats, water is a resource limited in time and space (Krausman et al. 2006). Waterholes are sources of water for many species of different taxa, such as reptiles, birds, and mammals (Martínez-Kú et al. 2008; Delgado-Martínez et al. 2018), and several of these species also use waterholes as refuge and resting areas (MartínezKú et al. 2008). However, species can also be negatively affected when visiting waterholes due to the increased risk of predation or competitive interactions (Rosenstock et al. 1999; Krausman et al. 2006; Hall et al. 2013; PereraRomero et al. 2021).

Herein, records of species visiting natural waterholes by camera traps during the dry season in a dry tropical forest of central México are documented. We obtained these records as part of monitoring and conservation activities, implemented within an extensive wildlife management unit (UMA in Spanish). The site is located 
in the Ejido Rancho El Salado, municipality of Jolalpan, in the southeast of the state of Puebla, in central México $\left(18^{\circ}\right.$ $\left.20^{\prime} \mathrm{N}, 98^{\circ} 57^{\prime} \mathrm{W}\right)$. The region is highly seasonal, with the occurrence of pronounced wet (from June to November) and dry (from December to May) seasons (INEGI 2009). The climate is warm sub-humid, with rainfall in the summer, temperatures range between $22-28^{\circ} \mathrm{C}$, and an annual precipitation of 800 to $1,000 \mathrm{~mm}$. The study area is located between 700 and 1,700 m (INEGI 2009). The predominant vegetation type is tropical dry forest, and the dominant species are trees of the Fabaceae and Anacardiaceae families (Martínez-Moreno et al. 2016). The main economic activities practiced in the area are seasonal agriculture and livestock production (INAFED 2019).

During the dry season (December 2015, May 2016, and April-May 2019), we placed 7 camera traps in 7 waterholes (also known as aguaje; Table 1) during 135 days, which contain water during the dry season. Cameras were programmed (models Primos Truth Cam $35^{\circledR}$ y Moultrie Game Spy $\left.D-55 I R^{\circledast}\right)$ to take three pictures every ten seconds and to remain active for 24 hours. We used field guides and specialized bibliography for species identification (Hall 1981; Reid 1997; Ceballos and Oliva 2005).

We recorded a total of 20 species of vertebrates from different taxonomical groups visiting the waterholes: four birds, one reptile, and 15 mammals including a species of goat (Table 1). The mammal species with the highest number of records were (decreasingly): Urocyon cinereoargenteus (grey fox, 95 records), Mephitis macroura (hooded skunk, 39 records), Odocoileus virginianus (white-tailed deer, 25 records), and Nasua narica (white-nosed coati, 22 records). All mammal species has been reported in the studied location (Ramírez-Carmona 2018) and in other waterholes in nearby areas (Mandujano and HernándezGómez 2019a; Mandujano and Hernández-Gómez 2019b).

Within the birds, there were four species recorded, been Zenaida sp. with the highest number of records (36 records; Table 1). Only on reptile species, Ctenosaura pectinata (guerreran spiny-tailed iguana) was recorded (Table 1).

We recorded co-occurrence (i.e., species found in the same region because a multitude of processes acting at different scales) between two species on several occasions: $M$. macroura - U. cinereoargenteus on two occasions, $N$. narica - U. cinereoargenteus on one occasion, M. macroura - Bassariscus astutus (ringtail) on one occasion, two individuals of $M$. macroura on one occasion, and two individuals of $U$. cinereoargenteus on two occasions (Figure 1). Although we obtained few observations of this co-occurrence (7 of 271 records), these observations have been rarely documented for these species. We also recorded behaviors such as playful behavior, grooming, and rubbing against stones, and some species were observed waiting for a turn to drink (Figure 1). Non-lethal interactions between species have been previously recorded between Taxidea taxus (American

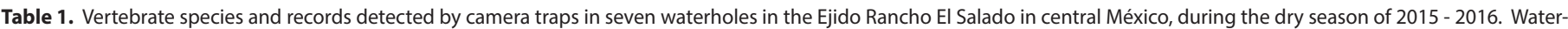

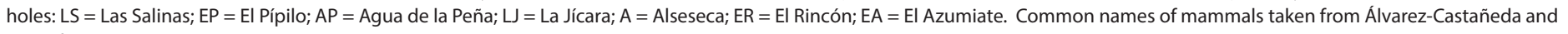
González-Ruiz (2018).

\begin{tabular}{|c|c|c|c|c|c|c|c|c|c|}
\hline Class & Species & Common Name & LS & EP & AP & LJ & A & ER & EA \\
\hline \multirow[t]{4}{*}{ Aves } & Ortalis poliocephala & West Mexican chachalaca & 7 & & & & 6 & & 3 \\
\hline & Zenaida sp. & White-winged dove & 20 & & & & & & 16 \\
\hline & Bubo virginianus & Great horned owl & 1 & & & & & & \\
\hline & Coragyps atratus & American black vulture & 3 & & & & 2 & & \\
\hline \multirow[t]{14}{*}{ Mammalia } & Didelphis virginiana & Virginia opossum & 3 & & & & & 3 & 1 \\
\hline & Dasypus novemcinctus & Nine-banded armadillo & 1 & & & & & & \\
\hline & Canis latrans & Coyote & 1 & & & & 1 & 1 & \\
\hline & Urocyon cinereoargenteus & Gray fox & 4 & & & 4 & & 3 & 84 \\
\hline & Leopardus pardalis & Ocelot & 1 & & & & & 1 & \\
\hline & Conepatus leuconotus & American hog-nosed skunk & & & & & & 1 & 1 \\
\hline & Mephitis macroura & Hooded skunk & & & & & & & 39 \\
\hline & Spilogale angustifrons & Southern spotted skunk & & & & & & 1 & \\
\hline & Bassariscus astutus & Ringtail & & & & & & 1 & 4 \\
\hline & Nasua narica & White-nosed coati & 3 & & & 1 & 3 & & 15 \\
\hline & Procyon lotor & Raccoon & & & 2 & & & & 1 \\
\hline & Odocoileus virginianus & White-tailed deer & 6 & 6 & 4 & & 2 & 4 & 3 \\
\hline & Dicotyles crassus & Eastern collared peccary & & & & 1 & & & \\
\hline & Sylvilagus floridanus & Eastern cottontail & & & & & 1 & & \\
\hline Reptilia & Ctenosaura pectinata & Guerreran spiny-tailed iguana & 5 & & & & & & \\
\hline Domestic species & Capra sp. & Goat & & & & & & & 1 \\
\hline Camera days & & & 15 & 15 & 15 & 15 & 15 & 15 & 45 \\
\hline
\end{tabular}




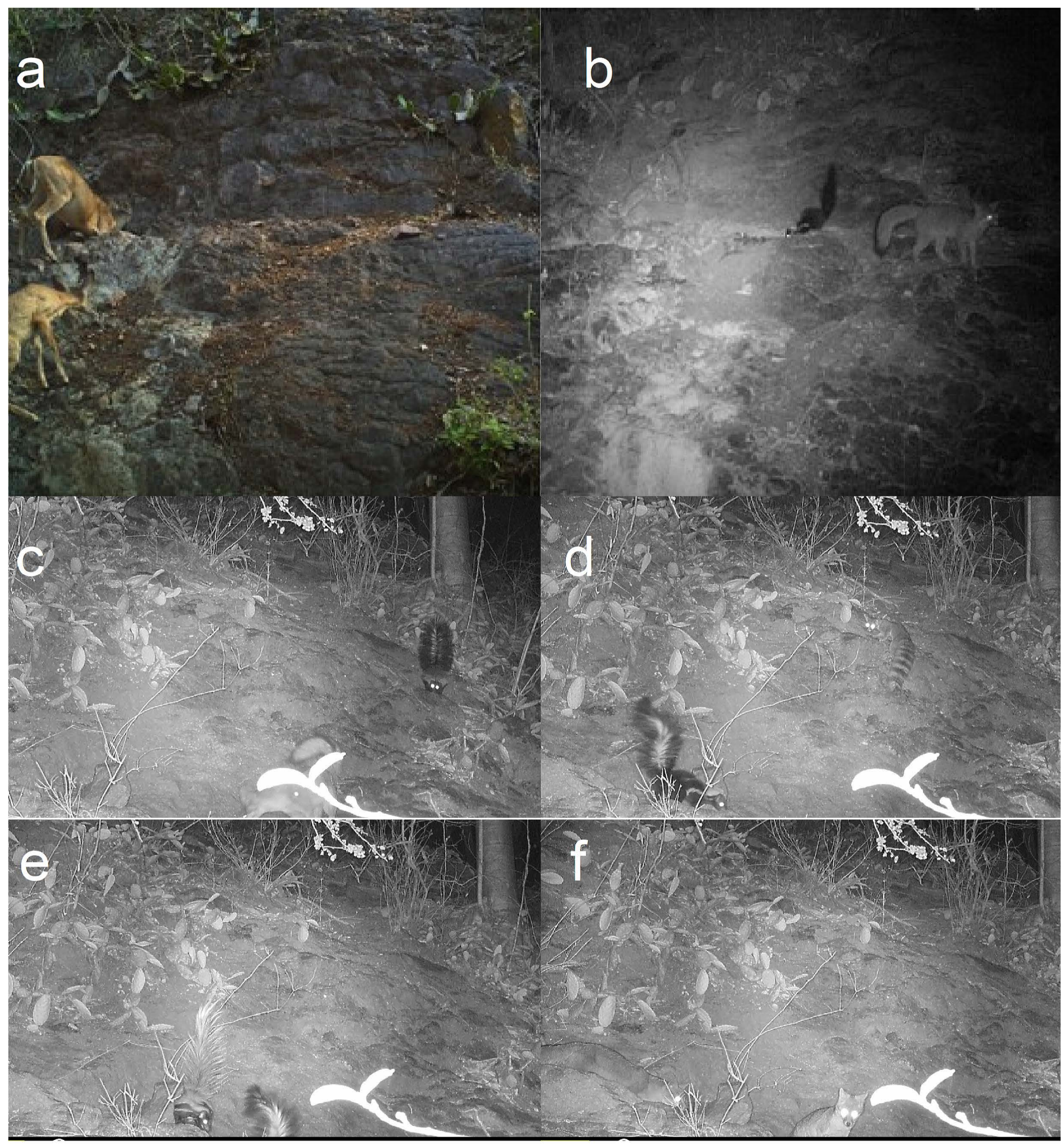

Figure 1. Co-occurrence in the waterhole between: a) two individuals of Odocoileus virginianus; b and c) Mephitis macroura and Urocyon cinereoargenteus individuals; d) Mephitis macroura and Bassariscus astutus individuals; e) two individuals of $M$. mephitis, and f) individuals of $U$. cinereoargenteus in the Ejido Rancho El Salado, in the southeast of the state of Puebla, in central México.

badger) and canids (Lehner 1981; Minta et al. 1992; Clark et al. 2015) and between U. cinereoargenteus and Spilogale angustifrons (southern spotted skunk; Farías-González and Vega-Flores 2019; Pérez-Irineo et al. 2020; Mejenes-López et al. 2021), as well as a co-occurrence between C. cinereoargenteus and M. macroura (Pérez-Irineo et al. 2020).
Water availability varies with the rainfall regime, nearby rivers have water only during the rainy season, and other deposits are small and temporary runoffs. There is, therefore, a severe water shortage for several months of the year. Thus, it is possible that the need to meet their water requirements outweighs the negative interactions among 
the species in our study site. In previous studies it has been recorded that the probability of negative interactions between species might increase especially when there are limited resources such as water (Rosenstock et al. 1999; Krausman et al. 2006; Perera-Romero et al. 2021). However, negative interactions, such as kicking, pushing, or chasing among species, when using waterholes were not recorded in our study site as in other studies (Rosenstock et al. 2004).

We recorded a high frequency of visits to the waterhole by Mephitis macroura. We also observed that it was possible to identify individuals through the coloration pattern of the back and tail, and at least four individuals were identified during the sampling period (Figure 2). Our records raise the possibility of carrying out population and ecological studies. These could include estimation of population size using capture-recapture models, and activity, residence and reproduction patterns, in order to establish conservation strategies for these species (Cuarón et al. 2016). The use of this variation in skunk coloration for the identification of individuals has been previously mentioned for striped skunks, Mephitis mephitis (Theimer et al. 2017), although it has not been applied for either of the two species thus far.

Waterholes contribute to the survival of several species and they serve as sites for resting and refuge against predators (Rosenstock et al. 1999; Martínez-Kú et al. 2008; Delgado-Martínez et al. 2018; Rich et al. 2019). Our records showed that they may also function as play and grooming areas and for interactions among species, then its conservation should be considered a priority in our study site.
Our study also emphasizes a basic aspect, but perhaps underestimated in recent years for the sake of quantitative analysis of a large amount of data resulting from the use of camera traps: the qualitative observation of animals through photos. These observations can reveal basic and interesting aspects of the natural history of species that allow us to improve the knowledge we have about them and infer hypotheses in this case about coexistence in the same place. Observation of wildlife was an essential part of the development of modern science through "natural historians" such as Aldo Leopold (Piccolo 2020). This knowledge is also important for conservation actions. The camera traps offer us the opportunity to observe the animals in activities that are not easy to record. Recent works where these "curious observations" are reported, such as those by López-Tello and Mandujano (2016), Farías-González and Vega-Flores (2019), Pérez-Irineo et al. (2020), MejenesLópez et al. (2021) are examples of what is discussed here.

\section{Acknowledgements}

We received logistic support from the Facultad de Ciencias Biológicas, Benemérita Universidad Autónoma de Puebla, and Red de Biología y Conservación de Vertebrados of the Instituto de Ecología, A. C. We appreciate the field help by local people of the Ejido Rancho El Salado. The authors thank the anonymous reviewers as well as the people who collaborated during field work. This research was funded by Consejo Nacional de Ciencia y Tecnología (CONACyT) by the project CB-2015-01-256549.

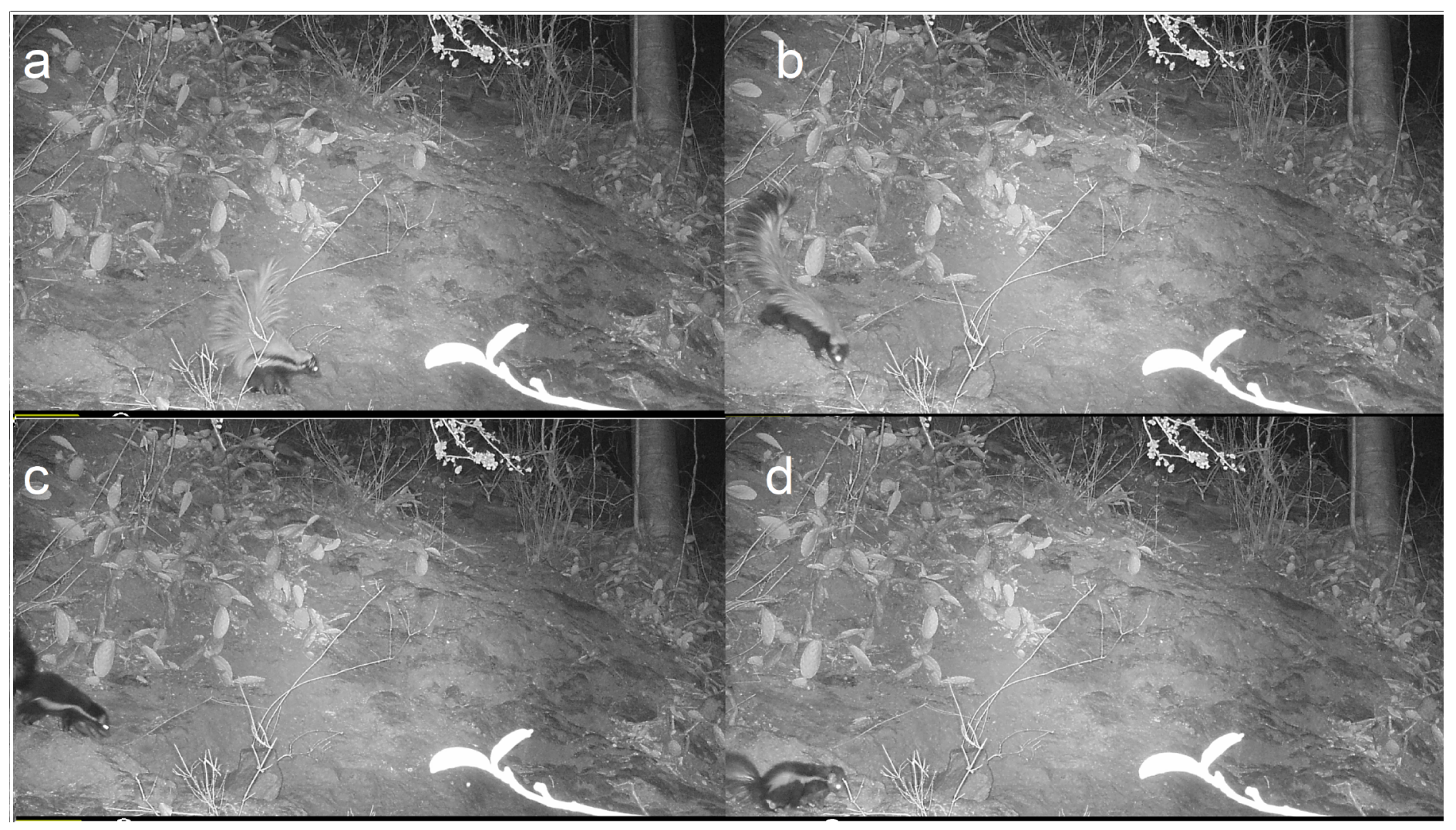

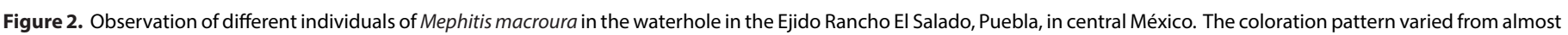
white $(a, b)$ to almost black $(c, d)$. 


\section{Literature cited}

Álvarez-Castañeda, S. T., and N. González-Ruiz. 2018. Spanish and English Vernacular Names of Mammals of North America. Therya 9:73-84.

Ceballos, G., and G. Oliva. 2005. Los mamíferos silvestres de México. CONABIO and Fondo de Cultura Económica. México City, México.

Clark, H. O., R. M. Powers, K. L. Uschyk, and R. K. Burton. 2015. Observations of antagonistic and nonantagonistic interactions between the San Joaquin kit fox (Vulpes macrotis mutica) and the American badger (Taxidea taxus). The Southwestern Naturalist 60:106-110.

Cuarón, A. D., J. González-Maya, K. Helgen, F. Reid, J. Schipper, AND J. W. Dragoo. 2016. Mephitis macroura. In: The IUCN Red List of Threatened Species 2016. https://www.iucnredlist.org. Accessed 25 September 2020.

Delgado-Martínez, C. E., F. Alvarado, E. Mendoza, S. FloresHernández, A. Navarrete, E. Navarrete, and F. Botello. 2018. An ignored role of sartenejas to mitigate water shortage hazards for tropical forest vertebrates. Ecology 99:758-760.

Farías-González, V., and C. N. Vega-Flores. 2019. Spotted skunks (Spilogale angustifrons) photo-captured following gray foxes (Urocyon cinereoargenteus) in tropical dry forest in central Mexico. Journal of Arid Environments 160:25-31.

Hall, R. 1981. The mammals of North American. Willey-Interscience. New York, U.S.A.

Hall, L. K., R. T. LaRsen, R. N. KNight, K. D. Bunnell, and B. R. McMillan. 2013. Water developments and canids in two North American deserts: A test of the indirect effect of water hypothesis. PLoS One 8:e67800.

Instituto Nacional para el Federalismo y el Desarrollo Municipal (INAFED). 2019. Enciclopedia de los municipios y delegaciones de México. Estado de Puebla. Downloaded at https://www. inafed.gob.mx/work/enciclopedia/EMM21 puebla/index.html.

Instituto Nacional de Estadística y Geografía (INEGI). 2009. Prontuario de información geográfica municipal de los Estados Unidos Mexicanos Jolalpan, Puebla Clave geoestadística 21087. INEGI. México City, México.

Krausman, P. R., S. S. Rosenstock, and J. W. C. III. 2006. Developed waters for wildlife: science, perception, values, and controversy. Wildlife Society Bulletin 34:563-569.

LehNeR, P. N. 1981. Coyote-badger associations. Great Basin Naturalist 41:347-348.

López-Tello, E., and S. Mandujano. 2016. Primer registro fotográfico de murciélagos hematófagos Desmodus rotundus (Chiroptera: Phyllostomidae) alimentándose de Odocoileus virginianus (Artiodactyla: Cervidae) en la Reserva de la Biosfera Tehuacán-Cuicatlán, México. Mammalogy Notes 3:17-19.

Mandujano, S., and C. A. Hernández-Gómez. 2019a. Uso de bebederos artificiales por venado cola blanca en una UMA extensiva en la Reserva de Biosfera Tehuacán-Cuicatlán, México. Agroproductividad 12:37-42.

Mandujano, S., and C. A. Hernández-Gómez. 2019b. Use of artificial drinking containers by collared peccary during the dry season in a semi-arid tropical habitat in central Mexico. Suiform Soundings 18:11-19.

Martínez-Kú, D. H., G. Escalona-Segura, and J. Vargas-ContreRAS. 2008. Importancia de las aguadas para los mamíferos de talla mediana y grande en Calakmul, Campeche, México. Pp.
449-468 in Avances en el estudio de los mamíferos de México II (Lorenzo, C., E. Espinoza, and J. Ortega, eds.). Asociación Mexicana de Mastozoología, A.C. México City, México.

Martínez-Moreno, D., J. Reyes-Matamoros, A. R. Andrés-HernánDez, AND L. Pérez-Espinosa. 2016. Flora útil de la comunidad "Rancho El Salado" en Jolalpan, México. Revista Iberoamericana de Ciencias 3:1-15.

Mejenes-López, S. M. A., X. Gálvez-Aguilera, G. Escalona-Segura, J. A. Vargas-Contreras, O. G. Retana-Guiascón, and G. Á. CabPaAt. 2021. First record of the coexistence of two mesocarnivores in the Yucatán Peninsula, México. Therya Notes 2:7984.

Minta, S. C., K. A. Minta, And D. F. Lott. 1992. Hunting associations between badgers (Taxidea taxus) and coyotes (Canis latrans). Journal of Mammalogy 73:814-820.

Pérez-Irineo, G., S. Mandujano, and E. López-Tello. 2020. Skunks and gray foxes in a tropical dry region: Casual or positive interactions? Mammalia 84:469-474.

Perera-Romero, L., R. Garcia-Anleu, R. B. McNab, and D. H. THORNTON. 2021. When waterholes get busy, rare interactions thrive: Photographic evidence of a jaguar (Panthera onca) killing an ocelot (Leopardus pardalis). Biotropica 53:367-371.

Piccolo, J. 2020. Celebrating Aldo Leopold's land ethic at 70. Conservation Biology 34:1586-1588.

Ramírez-Carmona, G. 2018. Comparación de métodos para determinar la diversidad de mamíferos carnívoros en tres UMA de la Mixteca Poblana y su uso por los pobladores. Tesis de licenciatura. Facultad de Biología, Benemérita Universidad Autónoma de Puebla. Puebla, México.

Reid, A. F. 1997. A field guide to the mammals of Central America and Southeast Mexico. Oxford University Press. New York, U.S.A.

Rich, L. N., S. R. Beissinger, J. S. Brashares, and B. J. Furnas. 2019. Artificial water catchments influence wildlife distribution in the Mojave Desert. The Journal of Wildlife Management 83:855-865.

Rosenstock, S. S., W. B. Ballard, and J. C. Devos. 1999. Viewpoint: Benefits and impacts of wildlife water developments. Journal of Range Management 52:302-311.

Rosenstock, S. S., M. J. Rabe, C. J. O'Brien, and R. B. Waddel. 2004. Studies of wildlife water developments in Southwestern Arizona: Wildlife use, water quality, wildlife diseases, wildlife mortalities, and influence on native pollinators. Research Branch Technical Guidance Bulletin 8:1-15.

Tanner, E. P., R. D. Elmore, S. D. Fuhlendorf, C. A. Davis, E. T. ThaCKer, AND D. K. Dahlgren. 2015. Behavioral responses at distribution extremes: how artificial surface water can affect quail movement patterns. Rangeland Ecology \& Management 68:476-484.

Theimer, T. C., D. T. RaY, and D. L. Bergman. 2017. Camera angle and photographic identification of individual striped skunks. Wildlife Society Bulletin 41:146-150.

\section{Associated editor: Nicté Ordoñez-Garza}

Submitted: February 18, 2021; Reviewed: June 1, 2021.

Accepted: June 11, 2021; Published on line: July 2, 2021. 